\title{
KARAKTERISTIK SERPIH MINYAK PADA FORMASI SINAMAR BERDASARKAN DATA PENGEBORAN BRP-02 DI DAERAH RANTAU PANDAN PROVINSI JAMBI
}

\section{CHARACTERISTICS OF OIL SHALES IN SINAMAR FORMATION BASED ON BRP-02 DRILL HOLE DATA AT RANTAU PANDAN AREA JAMBI PROVINCE}

\author{
Robet Lumban Tobing \\ Pusat Sumber Daya Mineral, Batubara dan Panas Bumi \\ trebortobing@gmail.com
}

\begin{abstract}
ABSTRAK
Serpih minyak merupakan batuan sedimen halus yang mengandung material organik dan dapat menghasilkan minyak ketika diekstraksi. Formasi Sinamar di daerah penelitian diduga merupakan formasi pembawa serpih minyak. Formasi ini terletak di bagian barat dan tenggara daerah penelitian dan diperkirakan berumur Oligosen. Berdasarkan data sumur BRP-02, litologi Formasi Sinamar di daerah penelitian tersusun oleh serpih, batulanau, batupasir dan batulempung karbonan. Tujuan penelitian ini untuk mengetahui karakter serpih minyak pada Formasi Sinamar yang tersebar di daerah Rantau Pandan, Kabupaten Bungo, Provinsi Jambi. Sebanyak 25 sampel batuan serpih diambil dari sumur pengeboran untuk dilakukan analisisanalisis: maseral, reflektansi vitrinit, pirolisis, total organic carbon (TOC) dan ektraksi batuan. Hasil analisis maseral yang dilakukan diketahui bahwa sampel batuan didominasi oleh maseral liptinit. Hasil analisis TOC menunjukkan bahwa kandungan material organik sampel batuan berkisar 3,40-17,60\% merupakan batuan sedimen yang berpotensi baik hingga sangat baik sebagai batuan sumber hidrokarbon. Tingkat kematangan material organik berada pada tahap belum matang hingga lewat matang. Berdasarkan data hasil ekstraksi batuan yang dilakukan terhadap sampel batuan diperoleh kandungan minyak berkisar 10 -150 liter/ton batuan atau dengan rata-rata 56 liter/ton batuan.
\end{abstract}

Kata kunci: serpih minyak, material organik, analisis pirolisis, analisis TOC, ekstraksi batuan

\section{ABSTRACT}

Oil shales is defined as fine sedimentary rock that contains organic material and can produce oil when extracted. The Sinamar Formation in the study area is thought to be a carrier for oil shales. This formation is located in the western and southeastern parts of the study area and is thought to have age of Oligocene. Based on BRP-02 well data, lithology of the study area consists of shales, siltstone, sandstone and carbonaceous clays. The purpose of this study was to determine the character of the oil shales in the Sinamar Formation, which is scattered in the Rantau Pandan area, Bungo Regency, Jambi Province. As many as 25 samples of rock obtained from drilling wells were analyzed for maceral, pyrolysis, total organic carbon (TOC) and extraction of rock. The results of the maceral analysis show that the rock samples are dominated by liptinite maceral. TOC analysis show that the organic material in the samples is about 3.40 to $17.60 \%$ which is potentially good to very good as hydrocarbon source rock. The level of organic maturity is immature to over maturity. Based on the rock extraction data from the samples, result of $t$ he oil content is about 10 to 150 liters/tons of rock with average 56 liters/tons of rock.

Keywords: oil shales, organic material, pyrolysis analysis, TOC analysis, extraction of rocks 


\section{PENDAHULUAN}

Serpih minyak (oil shales) merupakan batuan sedimen halus yang mengandung material organik dan dapat menghasilkan minyak ketika diekstraksi (Yen \& Chilingarian, 1976; Hutton, 1987; Dyni, 2006; Lee et al., 2007; Ruiz et al., 2012; Tobing, 2016). Komponen mineral yang terkandung pada serpih minyak umumnya terdiri dari mineral lempung, kuarsa, karbonat dan pirit (Crisp et al.,1987; Slatt \& Rodriguez, 2012; Tobing, 2016).

Serpih minyak terendapkan dalam suatu lingkungan yang tenang, baik lingkungan air asin maupun air tawar, seperti cekungan laut terisolasi, rawa-rawa, danau dan delta. Kandungan material organik serpih minyak umumnya berasal dari alga, tetapi dapat juga berasal dari sisa-sisa tetumbuhan (Yen \& Chilingarian, 1976; Tobing, dkk., 2011).

Tujuan penelitian ini untuk mengetahui karakter serpih minyak hasil pengeboran BRP-02 pada Formasi Sinamar yang tersebar di daerah Rantau Pandan, Kabupaten Bungo, Provinsi Jambi.

\section{METODE}

Penelitian ini menggunakan data hasil pengeboran dangkal hingga kedalaman 100 meter dan pengambilan sampel batuan hasil pengeboran untuk analisis laboratorium. Analisis laboratorium yang dilakukan terdiri dari analisis maseral, analisis reflektansi vitrinit (Rv) dengan menggunakan mikroskop sinar pantul, analisis pirolisis, analisis total organic carbon (TOC) dan ekstraksi batuan.

\section{GEOLOGI}

Geologi daerah penelitian mengacu pada peta geologi bersistem lembar Painan dan bagian timurlaut lembar Muarasiberut yang diterbitkan oleh Pusat Penelitian dan Pengembangan Geologi (Rosidi dkk., 1996). Daerah penelitian (Gambar 1) berada pada cekungan busur belakang (Harahap dkk., 2003) yang terletak di sebelah baratlaut Cekungan Sumatra Selatan.

Morfologi di daerah penelitian secara umum dicirikan oleh satuan perbukitan bergelombang sedang dan pedataran. Morfologi perbukitan bergelombang sedang menempati bagian baratdaya dengan ketinggian 150-400 meter di atas permukaan laut (dpl). Satuan pedataran menempati hampir seluruh daerah penelitian dengan ketinggian berkisar 25150 meter dpl.

Stratigrafi daerah penelitian tersusun oleh batuan pra-Tersier dan Tersier (Rosidi dkk., 1996). Kelompok batuan pra-Tersier berumur Perem hingga Jura, sementara kelompok batuan Tersier berumur Eosen hingga Pliosen. Kelompok batuan praTersier umumnya bertindak sebagai batuan alas berupa batuan granit, kemudian cekungan ini terisi oleh batuan sedimen Tersier. Statigrafi daerah penelitian dari yang tertua hingga muda dapat diuraikan sebagai berikut:

Formasi Palepat (Pp) berumur Perem, tersusun oleh lava dan tuf. Formasi ini juga mengandung batulanau keras terkersikkan, batutanduk, serpih dan batugamping hablur berlapis baik.

Diorit (Jd) berumur Jura, susunannya berkisar antara diorit, hornblenda sampai kuarsa dengan bintik-bintik mineral mafik, secara setempat terkena kloritisasi dan terubah sebagai stok. Batuan ini menerobos Formasi Palepat.

Granit (Jgr) berumur Jura, tersusun oleh granit, biotit, hornblenda sampai granodiorit dengan bintik-bintik mineral mafik, plagioklas jenis oligoklas.

Formasi Sinamar (Tos) berumur Oligosen, tersusun oleh konglomerat, batupasir konglomeratan, batupasir kuarsa mengandung mika, batupasir arkose, batulempung, napal, batubara dan serpih. Ketebalan formasi ini diperkirakan mencapai 750 meter. 


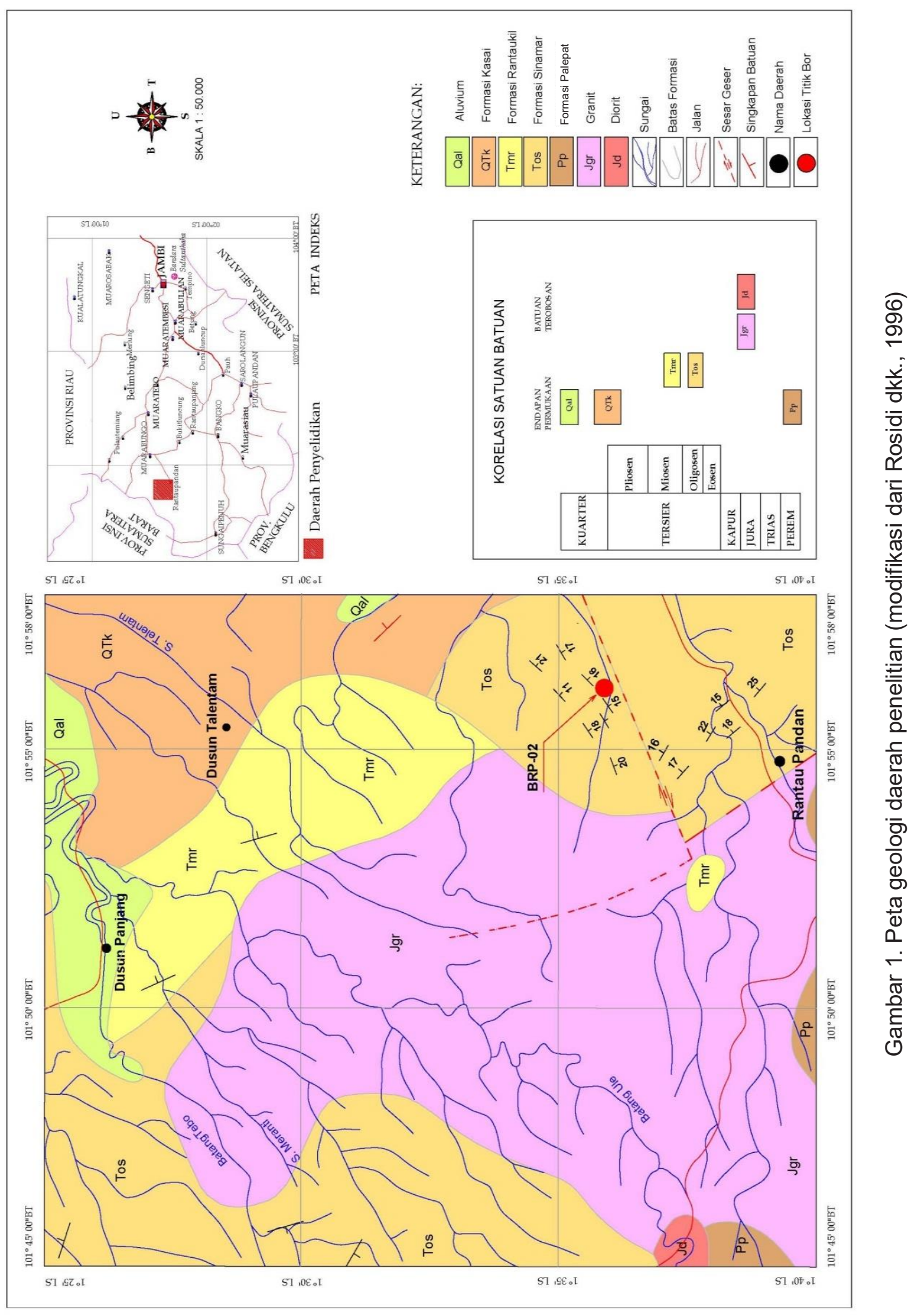


Formasi Rantauikil (Tmr) terendapkan di atas Formasi Sinamar, berumur Oligosen Akhir hingga Miosen, tersusun oleh batupasir lempungan, batupasir tufan, batupasir gampingan, batulempung pasiran, batulempung tufan dan lensa tipis batugamping.

Secara tidak selaras, di atas Formasi Rantauikil terendapkan Formasi Kasai (QTk) berumur Plio-Plistosen yang tersusun oleh tuf batuapung, batupasir tufan dengan sisipan bentonit dan sedikit lignit. Formasi ini memiliki ketebalan mencapai 700 meter. Pada kala Holosen terendapkan Aluvium (Qal), terdiri dari lempung, lanau, pasir dan kerikil.

Struktur geologi yang berkembang di daerah penelitian terdiri dari sesar geser menganan (dextral) dengan arah relatif timurlaut-baratdaya dan struktur antiklin dengan arah relatif tenggara-baratlaut.

\section{SUMBER DATA}

Data yang digunakan dalam tulisan ini berasal dari data sampel batuan hasil pengeboran prospeksi sumur BRP-02 pada Formasi Sinamar yang dilakukan oleh tim pengeboran, Pusat Sumber Daya Mineral Batubara dan Panas Bumi (PSDMBP) (Tobing dkk., 2016). Titik koordinat lokasi pengeboran ini berada pada koordinat 01³5'58,6" LS-101'56'10,6" BT. Sumur pengeboran ini menembus batuan yang merupakan bagian dari Formasi Sinamar hingga kedalaman 100 meter dengan ketebalan total batuan sedimen 97 meter dan lapisan tanah penutup 3 meter. Puncak lapisan batuan berada pada kedalaman 3 meter dengan kemiringan lapisan $22^{\circ}$. Urutan batuan hasil pengeboran mulai dari lapisan paling bawah ke lapisan paling atas adalah sebagai berikut:

Lapisan serpih pada kedalaman 100,00 hingga 23,00 meter, memiliki ciri batuan berwarna abu-abu kehitaman hingga kecoklatan, berukuran butir lempung, struktur berlapis, menyerpih, keras hingga agak keras. Di beberapa tempat terdapat sisipan batupasir berukuran halus hingga sedang, sisipan batulanau dan lempung karbonan. Pada kedalaman 23,00 hingga 14,40 meter ditemukan serpih berwarna abu-abu terang, berukuran butir lempung, menyerpih, lunak, terdapat sisipan batupasir berwarna abu-abu terang, berbutir sedang hingga kasar. Pada kedalaman 14,40 hingga 8,00 meter dijumpai lapisan batupasir berwarna abuabu terang, berukuran butir sedang hingga kasar, di beberapa tempat disisipi kerikil. Pada kedalaman 8,00 hingga 3,00 meter ditemukan endapan berukuran kerikil hingga kerakal.

Dari sumur BRP-02 tersebut diambil sebanyak 25 sampel serpih untuk diekstraksi dan 7 sampel dengan notasi BRP 2-03, BRP 2-06, BRP 2-10, BRP 2-14, BRP 2-17, BRP 2-21 dan BRP 2-25 dilakukan analisis-analisis: maseral, reflektansi vitrinit (Rv), pirolisis dan TOC. Data hasil analisis yang telah dilakukan dapat dilihat pada Tabel 1.

\section{HASIL DAN PEMBAHASAN}

\section{Hasil}

Di dalam analisis maseral dengan menggunakan mikroskop sinar pantul, kelompok maseral dapat dibedakan satu dengan yang lain berdasarkan derajat reflektivitasnya. Inertinit adalah maseral yang memiliki reflektivitas yang tinggi, sedangkan liptinit adalah sebaliknya. Pengamatan maseral liptinit lebih efektif dilakukan dengan model refleksi fluoresen. Intensitas fluoresen material organik berkurang dengan meningkatnya kematangan (Cook, 1982). Perbedaan sifat fisika dan kimia juga dapat menyebabkan keberagaman warna dan intensitas fluoresen untuk tiap jenis liptinit. Sifat - sifat fluoresen liptinit berhubungan erat dengan tingginya kandungan hidrogen. Kekayaan material organik dalam batuan sedimen dapat diperkirakan secara semi kuantitatif mengikuti standar pada Tabel 2. 
Tabel 1. Data hasil analisis : maseral, Rv, TOC, pirolisis dan ekstraksi batuan

\begin{tabular}{|c|c|c|c|c|c|c|c|c|c|c|c|c|c|c|c|c|}
\hline \multirow{2}{*}{ No. } & \multirow{2}{*}{\begin{tabular}{|c|} 
Kode \\
Sapel Batuan \\
\end{tabular}} & \multirow{2}{*}{ Litologi } & \multirow{2}{*}{\begin{tabular}{|c|} 
Kedalaman \\
$(\mathrm{m})$
\end{tabular}} & \multirow{2}{*}{\begin{tabular}{|c|} 
Minyak \\
(I/ton)
\end{tabular}} & \multicolumn{4}{|c|}{ Maseral (\%) } & \multirow{2}{*}{\begin{tabular}{c|} 
TOC \\
$(\%)$
\end{tabular}} & s1 & S2 & S3 & \multirow{2}{*}{$\begin{array}{c}\text { Tmaks } \\
\left({ }^{\circ} \mathrm{C}\right)\end{array}$} & \multirow{2}{*}{ PY } & \multirow{2}{*}{ HI } & \multirow{2}{*}{ OI } \\
\hline & & & & & $\mathbf{R v}$ & Liptinit & Vitrinit & Inertinit & & \multicolumn{3}{|c|}{ (mg/gr batuan) } & & & & \\
\hline 1 & BRP.2-01 & Serpih & $14-15$ & 70 & & & & & & & & & & & & \\
\hline 2 & BRP.2-02 & Serpih & $18-19$ & 60 & & & & & & & & & & & & \\
\hline 3 & BRP.2-03 & Serpih & $23-24$ & 15 & 0,42 & $10,0-50,00$ & $2,0-10,00$ & 0 & 3,4 & 0,2 & 13,34 & 0,41 & 438,3 & 13,54 & 393 & 12 \\
\hline 4 & BRP.2-04 & Serpih & $25-26$ & 50 & & & & & & & & & & & & \\
\hline 5 & BRP.2-05 & Serpih & $27-28$ & 20 & & & & & & & & & & & & \\
\hline 6 & BRP.2-06 & Serpih & $30-31$ & 115 & 0,41 & $10,0-50,00$ & $10,0-50,00$ & $0,1-0,5$ & 17,58 & 1,03 & 73,68 & 0,89 & 430,1 & 74,71 & 419 & 5 \\
\hline 7 & BRP.2-07 & Serpih & $33-34$ & 90 & & & & & & & & & & & & \\
\hline 8 & BRP.2-08 & Serpih & $35,5-36,5$ & 140 & & & & & & & & & & & & \\
\hline 9 & BRP.2-09 & Serpih & $39-40$ & 15 & & & & & & & & & & & & \\
\hline 10 & BRP. $2-10$ & Serpin & $42-43$ & 150 & 0,37 & $10,0-50,00$ & $2,0-10,00$ & 0 & 6,41 & 3,77 & 18,17 & 1,12 & 527,7 & 21,94 & 284 & 18 \\
\hline 11 & BRP.2-11 & Serpin & $45-46$ & 45 & & & & & & & & & & & & \\
\hline 12 & BRP. $2-12$ & Serpih & $48-49$ & 30 & & & & & & & & & & & & \\
\hline 13 & BRP.2-13 & Serpih & $51-52$ & 40 & & & & & & & & & & & & \\
\hline 14 & BRP.2-14 & Serpih & $54-55$ & 35 & 0,35 & $10,0-50,00$ & $0,5-2,00$ & 0 & 4,01 & 0,25 & 22,61 & 2,74 & 435,4 & 22,86 & 563 & 68 \\
\hline 15 & BRP.2-15 & Serpin & $58,5-59,5$ & 10 & & & & & & & & & & & & \\
\hline 16 & BRP.2-16 & Serpih & $63-64$ & 50 & & & & & & & & & & & & \\
\hline 17 & BRP.2-17 & Serpin & $67-68$ & 65 & 0,41 & $10,0-50,00$ & $2,0-10,00$ & 0 & 7,36 & 0,55 & 55,5 & 1,18 & 439,2 & 56,05 & 754 & 16 \\
\hline 18 & BRP.2-18 & Serpih & $69-70$ & 80 & & & & & & & & & & & & \\
\hline 19 & BRP.2-19 & Serpih & $73-74$ & 60 & & & & & & & & & & & & \\
\hline 20 & BRP.2-20 & Serpih & $78-79$ & 35 & & & & & & & & & & & & \\
\hline 21 & BRP.2-21 & Serpih & $82-83$ & 50 & 0,36 & $10,0-50,00$ & $0,5-2,00$ & 0 & 5,85 & 0,45 & 37,31 & 1,88 & 433,8 & 37,76 & 638 & 32 \\
\hline 22 & BRP.2-22 & Serpih & $87-88$ & 50 & & & & & & & & & & & & \\
\hline 23 & BRP.2-23 & Serpih & $90-91$ & 60 & & & & & & & & & & & & \\
\hline 24 & BRP.2-24 & Serpih & $94-95$ & 40 & & & & & & & & & & & & \\
\hline 25 & BRP.2-25 & Serpih & $97,5-98,5$ & 25 & 0,33 & $10,0-50,00$ & $2,0-10,00$ & 0 & 4,16 & 0,38 & 25,79 & 2,6 & 437,8 & 26,17 & 619 & 62 \\
\hline
\end{tabular}

Keterangan:

S1 : Hidrokarbon bebas yang dihasilkan pada temperatur $300^{\circ} \mathrm{C}$

S2 : Senyawa hidrokarbon dan oksigen yang dihasilkan pada temperatur berkisar $300^{\circ} \mathrm{C}-550^{\circ} \mathrm{C}$

S3 : Senyawa oksigen yang terbentuk pada saat temperatur menurun dari $550^{\circ} \mathrm{C}-300^{\circ} \mathrm{C}$

PY : Potential Yield

HI : Hidrogen Index

OI : Oxygen Index 
Tabel 2. Terminologi

kelimpahan

material organik (Cook, 1982)

\begin{tabular}{lc}
$\begin{array}{c}\text { Kelimpahan } \\
\text { Kualitatif }\end{array}$ & $\begin{array}{c}\text { Volume Material } \\
\text { Organik (\%) }\end{array}$ \\
\hline Absent/Absen & 0 \\
\hline Rare/Jarang & $<0.1$ \\
\hline Sparse/Sedikit & $0.1-0.5$ \\
\hline Common/Sedang & $0.5-2.0$ \\
\hline Abundant/Banyak & $2.0-10.0$ \\
\hline Major/Berlimpah & $10.0-50.0$ \\
\hline Dominant/Istimewa & $>50.0$ \\
\hline
\end{tabular}

Berdasarkan terminologi Cook (1982), secara mikroskopik, material organik sampel batuan dari daerah penelitian terdiri dari maseral liptinit berkisar 10,0$50,0 \%$ (berlimpah), maseral vitrinit berkisar $0,5-2,0 \%$ hingga 10,0-50,0\% (sedang hingga berlimpah) dan maseral inertinit berkisar $\quad 0,1-0,5 \%$ (sedikit). Secara keseluruhan, kandungan maseral terbanyak di dalam sampel batuan didominasi oleh maseral liptinit.

Analisis TOC dimaksudkan untuk mengetahui kelimpahan material organik pada suatu sampel batuan. Berdasarkan data hasil analisis TOC yang dilakukan, diketahui kandungan material organik pada sampel batuan berkisar 3,40-17,60\%. Menurut Waples (1985), batuan sedimen yang memiliki kandungan material organik $<0,5 \%$ tidak memiliki potensi sebagai batuan sumber hidrokarbon, sedangkan batuan sedimen dengan kandungan material organik antara 1,0-2,0\% merupakan batuan yang cukup baik sebagai batuan sumber hidrokarbon. Material organik $>2,0 \%$ merupakan batuan yang berpotensi baik hingga sangat baik sebagai batuan sumber hidrokarbon.

Plot silang antara TOC terhadap PY (potential yield) memperlihatkan bahwa potensi sampel batuan untuk menghasilkan hidrokarbon termasuk dalam kriteria sangat baik hingga istimewa (Gambar 2).

Plot silang antara $\mathrm{HI}$ (hydrogen index) terhadap Ol (oksigen index) pada diagram van Krevelen

(Gambar memperlihatkan bahwa material organik sampel batuan merupakan kerogen Tipe I dan Tipe II yang memiliki kecenderungan menghasilkan minyak.

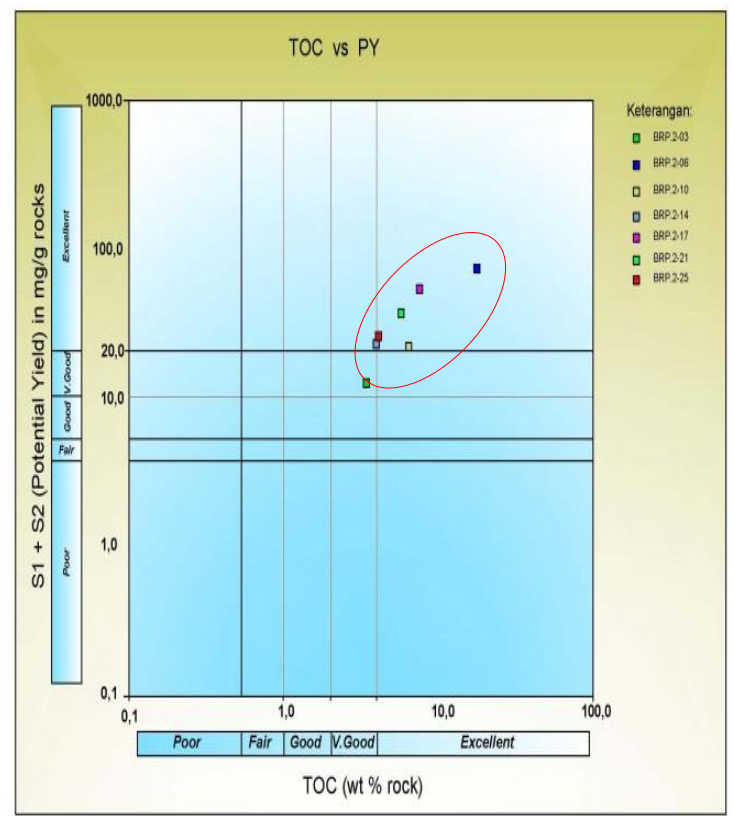

Gambar 2. Plot silang antara TOC vs PY

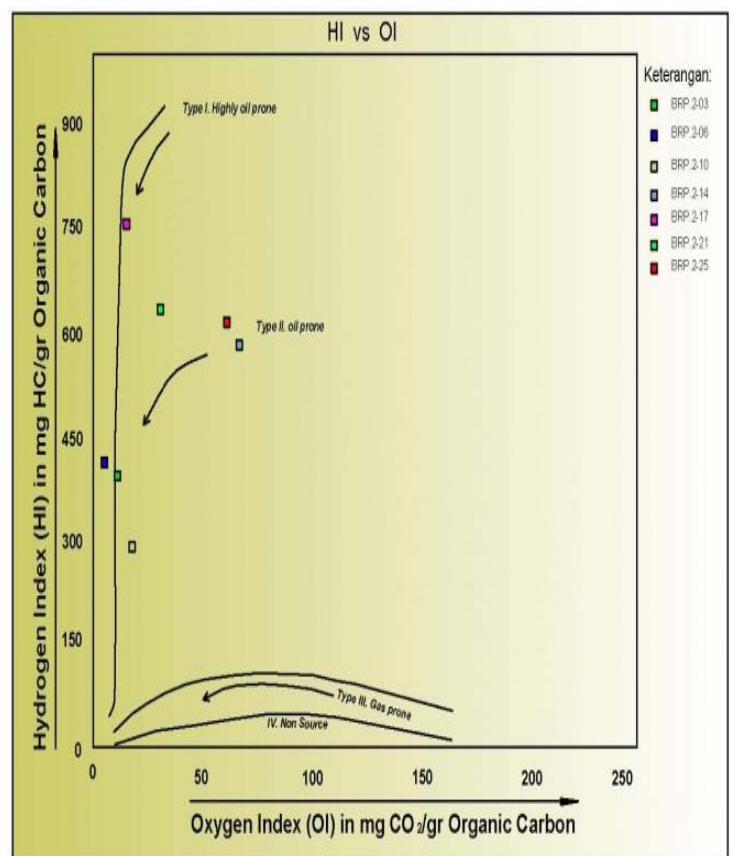

Gambar 3. Plot silang antara $\mathrm{HI}$ vs OI

Tahap kematangan termal material organik diperoleh dari analisis pirolisis dan reflektansi vitrinit. Secara umum, awal kematangan material organik memiliki nilai $\mathrm{Rv}$ sebesar $0,6 \%$ dengan nilai $\mathrm{T}_{\text {maks }}$ 
(temperatur maksimum) berkisar 435$445^{\circ} \mathrm{C}$. Puncak kematangan terjadi pada Rv 0,65-0,9\% dengan nilai Tmaks 445$450^{\circ} \mathrm{C}$ serta akhir kematangan terjadi pada Rv 0,9-1,35\% dengan nilai Tmaks 450$470^{\circ} \mathrm{C}$ dan lewat matang terjadi sekitar Rv $>1,35 \%$ dengan nilai $\mathrm{T}_{\text {maks }}>470^{\circ} \mathrm{C}$ (Peters \& Cassa, 1994).

Nilai Tmaks sampel batuan hasil analisis diperoleh berkisar $430,1-527,7^{\circ} \mathrm{C}$. Plot silang antara nilai Tmaks terhadap HI pada diagram (Gambar 4) menunjukkan bahwa material organik berada pada tahap belum matang (immature) hingga lewat matang (over mature).

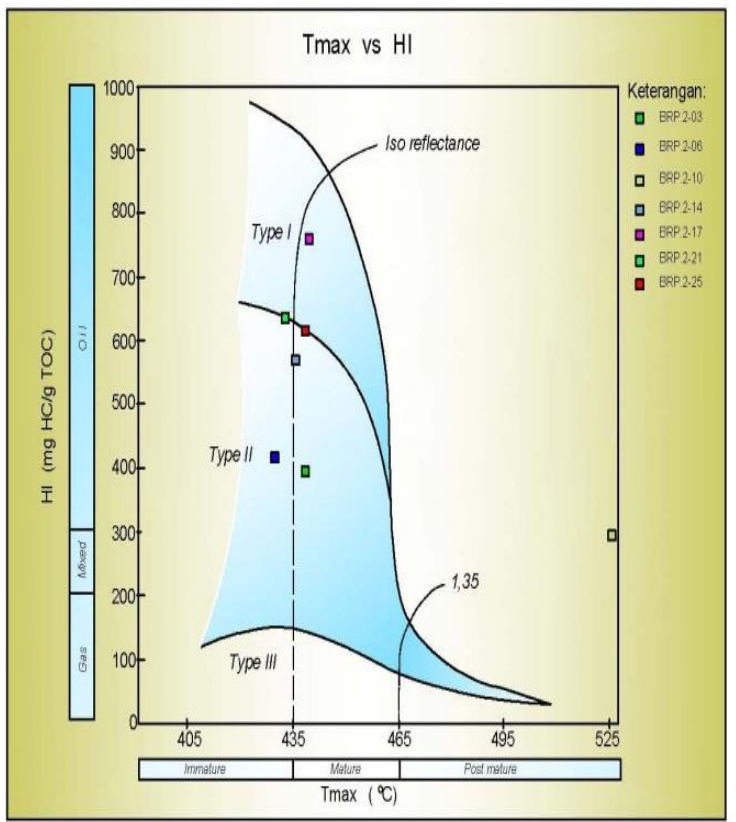

Gambar 4. Plot silang antara Tmaks vs HI

Berdasarkan data hasil analisis reflektansi vitrinit, nilai $\mathrm{Rv}$ berkisar 0,33-0,42\% mengindikasikan bahwa material organik berada pada tahap belum matang.

Banyaknya kandungan minyak di dalam sampel batuan dapat diketahui melalui proses ekstraksi batuan. Menurut Lee et al. (2007) proses ekstraksi batuan untuk menghasilkan minyak disebut dengan istilah fischer assay, yaitu suatu proses pemanasan sampel batuan hingga temperatur $298-773^{\circ} \mathrm{K}\left(25-500^{\circ} \mathrm{C}\right)$ untuk menghasilkan minyak. Dari hasil analisis ekstraksi batuan yang dilakukan terhadap sampel batuan diperoleh kandungan minyak berkisar 10 hingga 150 liter/ton.

\section{Pembahasan}

Hasil pengeboran sumur BRP-02, batuan di daerah penelitian dari lapisan paling bawah ke atas tersusun oleh serpih yang relatif tebal, berwarna abu-abu kehitaman hingga kecoklatan, berukuran butir lempung, menyerpih, keras hingga agak keras. Kandungan material organik sampel batuan didominasi oleh maseral liptinit, sedangkan vitrinit dan inertinit hadir dalam jumlah sedikit. Liptinit adalah kelompok maseral yang berasal dari zat lilin, lipid dan bagian dari tumbuhan seperti spora, kutikula dan resin (Hutton, 2006). Liptinit merupakan kerogen Tipe II yang memiliki kecenderungan untuk menghasilkan minyak (Waples, 1985).

Jumlah keseluruhan kandungan material organik pada sampel batuan dikategorikan berlimpah. Kelimpahan material organik dan ketebalan endapan serpih merupakan penciri suatu kondisi lingkungan pengendapan yang relatif tenang dan produktivitas organik melimpah pada saat terjadinya proses sedimentasi.

Hasil analisis TOC, kandungan material organik pada sampel batuan berkisar 3,40$17,60 \%$ mengindikasikan bahwa endapan serpih di daerah penelitian memiliki potensi baik hingga sangat baik untuk menghasilkan hidrokarbon (Waples, 1985). Nilai HI berkisar 284 hingga 754 mgHC IgramTOC mengindikasikan bahwa sampel batuan memiliki kecenderungan menghasilkan minyak dan sedikit gas (Peters dan Cassa, 1994).

Berdasarkan data hasil pengukuran Tmaks, terdapat 2 sampel batuan dengan notasi BRP 02-06 dan BRP 02-21 dikategorikan belum matang, 4 sampel batuan dengan notasi BRP 02-03, BRP 0214, BRP 02-17 dan BRP 02-25 dikategorikan awal matang dan 1 sampel batuan dengan notasi BRP 02-10 dikategorikan lewat matang. Terjadinya anomali tingkat kematangan pada sampel dengan notasi BRP 02-10 diduga 
disebabkan terjadinya perubahan temperatur yang cukup tinggi di sekitar lokasi sampel batuan tersebut. Meningkatnya kematangan suatu material organik terjadi ketika material organik tersebut mengalami temperatur tinggi untuk jangka waktu yang cukup lama (Waples, 1985). Perubahan temperatur tersebut dapat disebabkan oleh oleh penurunan cekungan, pembebanan lapisan penutup, konduktivitas panas yang berasal dari batuan di sekitarnya atau tekanan akibat tektonik (Stone \& Cook, 1979; Teichmuller, 1987; dalam Herudiyanto, 2003).

Hasil analisis Rv menunjukkan bahwa seluruh sampel batuan dikategorikan belum matang. Terdapat perbedaan hasil pengukuran antara Tmaks dan Rv pada 5 sampel batuan dengan notasi BRP 02-03, BRP 02-10, BRP 02-14, BRP 02-17 dan BRP 02-25. Berdasarkan hasil analisis pirolisis, kelima sampel ini dikategorikan berada pada tahap awal matang hingga lewat matang, sementara hasil pengukuran reflektansi vitrinit mengindikasikan bahwa sampel batuan dikategorikan berada pada tahap belum matang. Menurut Subroto (2004), analisis reflektansi vitrinit memiliki kelemahan dalam menentukan tingkat kematangan suatu batuan sumber hidrokarbon. Hal ini disebabkan oleh maseral vitrinit yang ditemukan pada sampel batuan sedimen halus merupakan material organik yang telah tertata ulang atau material lain (bukan vitrinit) yang terpadatkan dan sering teramati sebagai maceral vitrinit, sehingga tingkat kematangan yang teramati tidak sesuai dengan nilai kematangan sebenarnya.

Plot silang antara minyak hasil ekstraksi batuan terhadap kedalaman batuan (Gambar 5) mengindikasikan bahwa sampel batuan yang paling potensial berada pada kedalaman 30 meter hingga 42 meter dengan kandungan minyak 90 liter/ton hingga 150 liter/ton.

Lapisan berikutnya pada kedalaman 62 meter hingga 90 meter memperlihatkan kandungan minyak 35 liter/ton hingga 80 liter/ton dan lapisan batuan paling atas pada kedalaman 14 meter hingga 18 meter dengan kandungan minyak 60 liter/ton hingga 70 liter/ton. Bila dirata-ratakan kandungan minyak yang diperoleh dari 25 sampel batuan adalah 56 liter/ton batuan. Nilai ekonomis serpih minyak diperkirakan berkisar 25 liter/ton hingga 40 liter/ton batuan (Dyni, 2006).

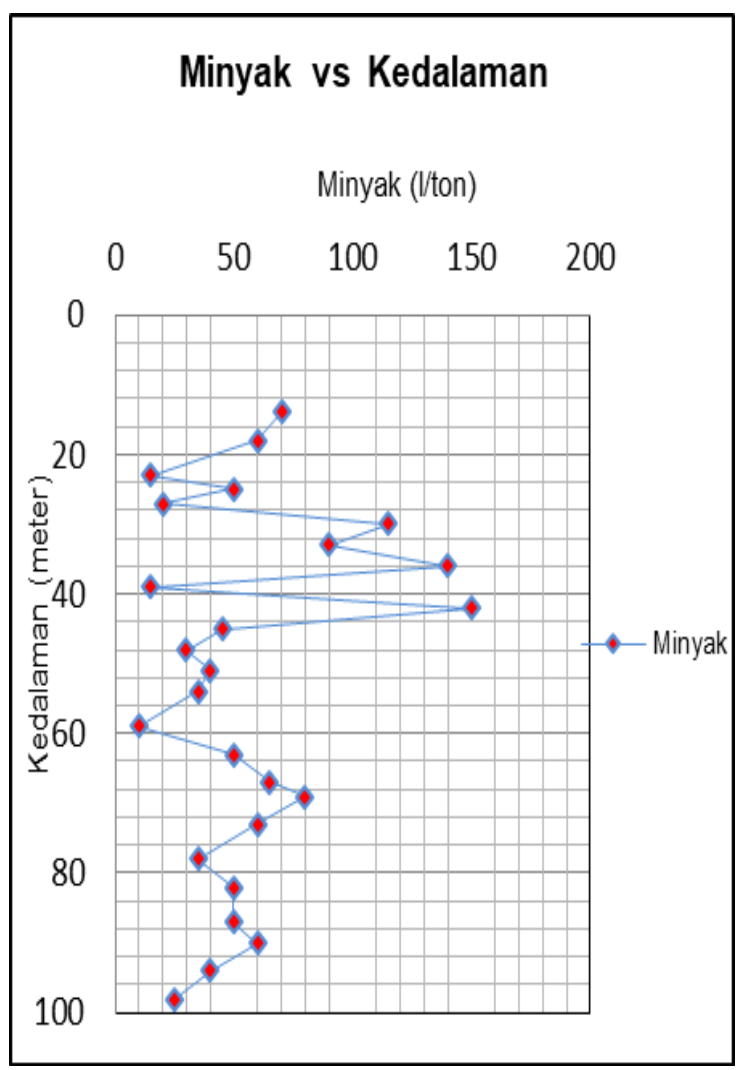

Gambar 5. Plot silang antara Minyak vs Kedalaman sampel batuan.

\section{KESIMPULAN}

Litologi batuan sumur BRP-02 pada Formasi Sinamar dari bagian bawah ke atas tersusun oleh serpih, batulanau, batupasir dan batulempung karbonan. Kandungan material organik sampel batuan didominasi oleh maseral liptinit dengan kategori berlimpah. Nilai TOC berkisar $3,40 \%$ hingga $17,60 \%$ dengan tingkat kematangan material organik berada pada tahap belum matang hingga lewat matang. Kandungan minyak hasil ekstraksi sampel batuan berkisar 10 hingga 150 liter/ton batuan atau dengan rata-rata 56 liter/ton batuan. Berdasarkan 
data-data hasil analisis yang dilakukan dapat diketahui bahwa endapan serpih pada Formasi Sinamar di daerah penelitian merupakan batuan serpih minyak (oil shales) yang memiliki potensi baik hingga sangat baik untuk menghasilkan hidrokarbon.

\section{UCAPAN TERIMA KASIH}

Penulis mengucapkan terima kasih kepada Kepala PSDMBP, Koordinator Bidang Batubara dan rekan-rekan kerja di lingkungan PSDMBP yang telah memberikan masukan dan saran sehingga tulisan ini dapat dipublikasikan.

\section{DAFTAR PUSTAKA}

Cook, A.C. (1982): The origin and petrology of organic matter in coal, oil shales and petroleum source rocks, University Wollongong, Australia.

Crisp, P.T., Ellis, J., Hutton, A.C., Korth, J., Martin, F.A., and Saxby, J.D. (1987): Australian oil shale: A compendium of geological and chemical data, University of Wollongong, Australia.

Dyni, J.R. (2006): Geology and resources of some world oil-shale deposits, Scientific investigation report 20055294, USGS, Reston, Virginia.

Harahap, B., Syaiful, B., Baharuddin, Suwarna, N., Panggabean, $\mathrm{H}_{\text {., }}$ Simanjuntak, T.O. (2003), Stratigraphic Lexicon of Indonesia, (Special Publication No. 29), Geological Research and Development Centre, Bandung.

Herudiyanto (2003): Petrographic characteristics of some Indonesian oil shales based on microscopic analysis: Workshop on oil shales resources in Indonesia, Directorate of Mineral Resources Inventory, Special Publication, No.102.

Hutton, A.C. (1987): Petrographic classification of oil shales: International Journal of Coal Geology, vol.8 (3), p. 203-231.
Hutton, A.C. (2006): Organic petrography and classification of oil shales: Oil shales workshop, University of Wollongong, Australia.

Lee, S., , Speight, J.G., and Loyalka, S.K. (2007): Handbook of alternative fuel technologies, CRC Press, Taylor and Francis Group.

Peters, K.E. and Cassa, M.R. (1994): Applied source rock geochemistry: The petroleum system from source rock to trap, AAPG, Memoirs 60.

Rosidi, H.M.D., Tjokrosapoetro, S., Pendowo, B., Gafoer, S., dan Suharsono, (1996), Peta Geologi Lembar Painan dan Bagian Timurlaut Muarasiberut, Sumatra, Pusat Penelitian dan Pengembangan Geologi, Bandung.

Ruiz, I. S., Flores, D., Filho, J. G. M., Hackley, P. C., (2012), Review and update of the applications of organic petrology: Part 1, geological applications, International Journal of Coal Geology, vol. 99, p. 54-112.

Slatt, R. M. and Rodriguez, N., (2010), Comparative Sequence Stratigraphy and Organic Geochemistry of North American Unconventional Gas Shales: Commonality or Coincidence, AAPG Hedberg Conference, Austin, Texas.

Subroto, E.A., (2004): Pengenalan geokimia petroleum, Departemen Teknik Geologi, ITB, Bandung.

Tobing, R. L., Wibisono, S.A., Simatupang, D.P., (2011); Petrografi organik dan retorting conto batuan hasil pemboran Sumur BH-02 Anggota Atas Formasi Telisa untuk mengetahui potensi serpih minyak di Daerah Padanglawas, Sumatra Barat: Buletin Sumber Daya Geologi, vol.6 (3), p. 161-169.

Tobing, R. L., Triono, U., Priyono., Setiawan, W., (2016), Prospeksi Bitumen Padat di Daerah Dusun Panjang, Kabupaten Bungo, Provinsi Jambi, PSDMBP, Bandung. 


\section{MAKALAH ILMIAH}

Tobing, R. L., (2016); Kematangan termal dan estimasi kandungan minyak endapan serpih Formasi Sinamar di Daerah Dusun Panjang, Provinsi Jambi: Buletin Sumber Daya Geologi, vol.11 (2), p. 93-101.
Waples, D.W. (1985): Geochemistry, in petroleum exploration, International Human Resources Development Coorporation, Boston.

Yen, T.F. and Chilingarian, G.V. (1976): Oil shale, Elsevier, Amsterdam.

\begin{tabular}{ll}
\hline Diterima & $:$ 3 November 2020 \\
Direvisi & $: 24$ Februari 2021 \\
Disetujui & $: 24$ Mei 2021
\end{tabular}

